\title{
Role of culture in the emotional response towards komodo dragon in Komodo and Rinca Islands of Komodo National Park
}

\author{
Arzyana Sunkar ${ }^{1, *}$, Mirza Dikari Kusrini ${ }^{1}$, and Fitria Suci Ramadhani $^{2}$ \\ ${ }^{1}$ Department of Forest Resources Conservation and Ecotourism Faculty of Forestry, IPB University, 16001 Bogor, Indonesia \\ 2 IUPHHK-HA PT. Sarmiento Parakantja Timber (SARPATIM), 74312 Kotawaringin Timur, Indonesia
}

\begin{abstract}
Human emotions towards wildlife were seldom considered in wildlife conservation. This study seeks to identify, explore and understand the local communities perceptions and interactions with Komodo dragons. Data were collected from February to April 2018 in Komodo Village and Rinca Village of Komodo National Park, using close and semi-open questionnaires, three-scale Likert statements and interviews with 60 respondents. Although $98.5 \%$ considered Komodo as a dangerous species, in total, $60.6 \%$ of Komodo villagers had positive perceptions of their interactions with Komodo, while $47.6 \%$ of Rinca's had moderate perceptions. Komodo attacks were less reported in Komodo Village despite the more frequent direct encounters. Komodo villagers have learnt how to adjust to the dangers, with $13 \%$ showed no actions during an encounter with the dragon, $77 \%$ pelt the dragon with rocks and $10 \%$ pulled it by the tail. On the contrary, 50\% of Rinca Villagers, although showed no actions, but reported the sightings, $20 \%$ pelt it with rocks, $27 \%$ herd it with sticks and $3 \%$ hit it with wood. The different responses correlated with the different cultural beliefs and values towards Komodo. All Rinca villagers were migrants with no cultural attachments to the reptile, while for Komodo villagers, the dragons were perceived to be cousins, hence should not be harmed. Such perceptions have resulted in the approximately $83 \%$ of Komodo villagers believed they could co-exist with the dragons, and showed higher supports for its conservation (81.5\%) than Rinca villagers $(65.3 \%)$. This study confirms the importance of integrating local cultural values in building supports for conservation.
\end{abstract}

\section{Introduction}

Humans and wildlife have interacted by sharing natural resources for thousands of years. If competition occurs both in terms of food and space [1-4], the resultant negative impacts [5-6] would often threaten the survival of the wildlife [1-4]. This issue becomes worse if the species are considered dangerous and feared, since people's perceptions of feared species enhance their killings, as found in the studies on wolves by BrowneNuñez and Taylor [7] in America and Álvares 2004 in [8] in Portugal. Driven by fairy tales and religious beliefs, wolves were regarded as threats to personal safety and livestock, which have led to their eradication. Similarly, Prokop and Tunnicliffe [9] have observed that the misinterpretation about bats and spiders grounded on common folklore has resulted in negative values towards the animals.

Similar to wolves, reptiles have since ancient time, experienced the same fate [10], especially since of the entire human and wildlife interactions, conflicts with dangerous reptiles are the most often causing death [11].
Snakes and crocodiles [12-15] can also potentially injure or hurt humans, causing physical harm or combinations of both [16]. The danger would increase if they are dwelling in tight proximity to man, such as crocodiles that have been reported to be responsible for most of the human deaths in Africa [17]. Although not all reptiles are dangerous, the misperception that all reptiles are venomous is often found. Rahman et al. [18] found three non-venomous monitor lizards in Bangladesh were killed because the people perceived the lizards as venomous, even the local fisherman, conducted annual killing of the lizards for trivial causes. Although not responsible for major economic losses, and most are harmless, reptiles are often feared and persecuted [19]. Padney et al. [20] concluded that the killing of snakes in Southern Nepal appears to be the result of extreme negativity that originates from fear. Kellert [21] states that a negative value is shown when people express feelings of fear, distaste, and dislike for some species or creatures. Nolan et al. [22], has also shown that snakes, lizards and turtles, were the least appreciated animals compared to mammals, birds or fishes, which complicate their

\footnotetext{
* Corresponding author: arzyanas@gmail.com
} 
protections [23]. Since attitude encompasses both feelings and beliefs, it has both affective and cognitive components [18], hence it is exceedingly significant to consider how tales, folklore, misperception, and negative values affected wildlife conservation.

Kellert [24] concludes that the emotional response towards wildlife is influenced by the people's perceptions and beliefs. Human perceptions and attitudes towards animals are becoming of increasing importance in conservation and welfare [25], especially in the conservation of threatened species, including reptiles [26]. A change in perception of how one considers an animal or wildlife will cause significant impacts on the protection of wildlife, such as demonstrated aside the research on wolves in the USA, where the misperception of the wolf have changed, and people immediately see them as an inbuilt component of the ecosystem [7]. Understanding the driving factors behind people's attitudes towards certain wildlife can therefore aid the manager of a protected country in designing conservation programmes for the species. This becomes necessary if the endangered species is also the flag species of the protected area [27-28], such as the giant Komodo monitor lizard (Varanus komodoensis) or known as the Komodo dragon.

Komodo inhabits several islands within East Nusa Tenggara and is protected nationally and internationally within the Komodo National Park (KNP) of Indonesia. Inside the park, Komodo dragon can also be found inhabiting the Komodo Village and Pasir Panjang Village. Keeping in mind that the dragon is considered dangerous and that these two villages are inhabited by 3,424 residents [29] with a Komodo dragon population of 3,014 individuals, a $0.75 \%$ reported annual Komodoattacks [30] on the residents are very low. History of ceasing Komodo attacks was also reported by Murphy \& Walsh [31] and C. Ciofi (pers. comm. June 2009 in [32]) who commented that now, humans are more dangerous to the Komodo dragons than the reverse. Nevertheless, conflicts with Komodo still occur related to the predation of livestock by the dragon. Therefore, an apprehension of human attitudes towards Komodo is important for decision making in the KNP management as a form of preventive action in dealing with human conflicts and dangerous reptiles, especially in villages within the KNP.

\section{Material and Methods}

The study was conducted from February to April 2018, in Komodo National Park of East Nusa Tenggara Province, Indonesia. Specifically, data collection was carried out in Komodo Village on Komodo Island and Rinca Village of Pasir Panjang Village, Rinca Island. Respondents were selected using accidental sampling and quota sampling, totalling to 60 respondents (30 individuals from each island). Semi-structured interviews were conducted using semi-open and closed questionnaires to identify the characteristics of the respondents, forms of attacks and interactions with the dragons, while closed questions used to analysethe people's perceptions of Komodo using a three point positive Likert statements with four alternative responses for each statement, i.e., 0 (don't know), 1 (disagree), 2 (neither), and 3 (agree) with consecutive scores. There was a total of 14 Likert statements, of which eight were on the interactions with Komodo and six on the conservation of Komodo. To determine the level of danger of Komodo dragon from the people's perceptions, a set of reptile pictures was shown to the respondents of which they rate the danger. The pictures comprised of Komodo, water monitor lizard, crocodile and three dangerous snakes found within the national park.

Data that have been collected were later analysed using descriptive statistics and interpreted in the forms of tables and graphs. Frequencies (percentage of responses of each category) were used to analyse the Likert scale. In each study site, the individual scores were then summed up and then divided by the number of the variables being asked, to determine the response value. The perceptions were then grouped based on the score of each respondent's answer (Table 1).

Table 1. Level of perception based on respondents' responses

\begin{tabular}{|llll|}
\hline No & Likert Score & Total Score & Level \\
\hline 1 & $0-1$ & $1-30$ & Bad \\
2 & 2 & $31-60$ & Average \\
3 & 3 & $61-90$ & Good \\
\hline
\end{tabular}

\section{Result and Discussion}

\subsection{Socio-Demographic Characteristics of Respondents}

Limited attention to socio-economic and cultural factors are, according to Keller et al. [33] and Igoe (2003 in [34]), the factors responsible for conservation failures. By paying attention to socio-economic aspects, several protected areas have succeeded in reducing pressure and levels of their vulnerability. Considering that socioeconomic characteristics of the community are closely related to the success of conservation [34-35], the strategy to achieve biodiversity conservation in national parks must focus more on the social dimensions [34, 36]. Unfortunately, not many protected areas have taken into consideration the socio-economic importance of their biodiversity conservation activities.

The respondents of the two studied villages (Komodo and Rinca) had similar age classes, with respondents of Komodo Village having age classes between 31 to 80 years old and dominated by age class between $36-45$, while the slightly younger Rinca villagers were between 26 to 72 years old, and dominated by age class $25-35$. As many as $20 \%$ of the Komodo residents were between $25-35,33 \%$ between $36-45,20 \%$ between $46-55,7 \%$ between $56-65$ and $20 \%$ above 65 years old. Meanwhile, the Rinca population samples showed that $30 \%$ were aged between $25-35,10 \%$ between $36-45,23 \%$ between $46-55,13 \%$ between $56-65$ and $24 \%$ above 65 years old. 
The residents of the Komodo Village claimed they have been living in the area, long prior to the area's designation as a national park [37]. This fact was also supported by the statements of Verheijen [38] and a number of anthropologists [39-40] who wrote of the existence of Ata Modo (Komodo people) or the so called native explorers of Komodo Island. In addition, the residents of Komodo Village also use local dialect called Komodo dialect. Rinca villagers on the other hand, originated from various areas dominated by migrants from Flores (also in East Nusa Tenggara) such as Labuan Bajo, Ruteng, Warloka, Pota, Riung, and Maumere (Figure 1), so the local languages varied.

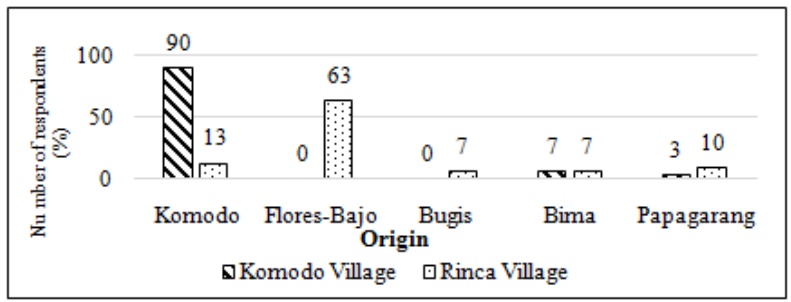

Fig. 1. Origins of respondents in Komodo and Rinca Villages

Based on their livelihoods, the residents of Rinca Village worked as fisherman and some women worked as sellers of dry fish, while the Komodo villagers were more diversity in terms of livelihoods (Figure 2), although dominated by the tourism sector. Prior to its designation as a Tourism Village in 2013, the majority of Komodo Village residents worked as fisherman [41-42] but along with the development of KNP as a tourist destination, the residents have begun working as tour guides, accessories makers, and hand-carvers [42]. In earlier periods, during certain months, residents of Komodo Village would harvest forest products such as tamarind (Tamarindus indica), srikaya (Annona squamosa), and honey for additional incomes (version 1987), whereas the residents of Rinca Village would only collect tamarind and honey.

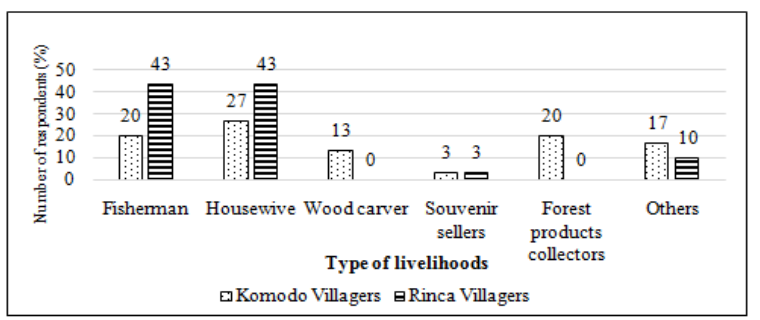

Fig. 2. Various livelihoods in Komodo and Rinca Villages

\subsection{Perceptions of the Human-Komodo Interactions}

Every human being has a different perception about wildlife, which affects his/her attitude towards wildlife and their habitats [24] and influenced by emotions, motivations, expectations and certain values [43]. According to Auffenberg [44], six out of the 28 dangerous reptiles in Indonesia are found within the KNP. The villagers in the study sites viewed four reptiles existed in KNP as dangerous (Table 2) and known to attack human, i.e. Varanus komodoensis, Daboia siamensis, Naja sputatrix, and Trimeresurus insularis, with $98 \%$ considered Komodo as the most dangerous.

Table 2. Perceptions of fear by the villagers towards Komodo

\begin{tabular}{lcc}
\multicolumn{1}{c}{ Reptile } & Fear (\%) & Category \\
\hline Varanus komodoensis & 98 & Dangerous \\
Daboia siamensis & 93 & Dangerous \\
Naja sputatrix & 93 & Dangerous \\
Trimeresurus insularis & 93 & Dangerous \\
Crocodylus porosus & 43 & Not Dangerous \\
Varanus salvator & 2 & Not Dangerous \\
\hline
\end{tabular}

Larger reptile species such as Komodo dragon were evaluated as more frightening due to their large body size. It is thus possible that these animals evoked high fear in the respondents due to their physical appearance, which apart from body size, also include sharp edges, and the dark colour [45] and not due to their real dangerousness. Based on research by Davey [46] and Ware et al. [47], lizard is categorised as feared animal, meaning that the species is highly feared without posing real danger [48]. From an evolutionary perspective, fear and disgust, in particular, represent a biologically adaptive way of responding to situations that may be potentially life-threatening [49].

Attack on humans is the most human-wildlife conflict of concern. During the period of 2017, there were six people who had been attacked by Komodo in Komodo Village and one that was bitten by the juvenile Komodo (Table 3). The locations of the attacks were in the garden, savanna, forest and village. Thus far, there has not been any growth in the number of attack cases based on the data from BTNK [50], where 32 cases of Komodo attacks from 1974 to 2017 were recorded, with the highest frequency occurring in Loh Buaya (Rinca Island) (Table 3). This is inline with Rismayani [51] who found that Komodo attacks on humans occurred more on Rinca Island than in Komodo Village.

Rinca Island is one of the highest attacked locations with 20 attack cases compared to 12 cases in Komodo Island. Most of the attacks in Komodo Village occurred on the border of the village and savanna [52], while in Rinca Village, the attacks occurred between the border of the village and forest. The case of Komodo dragon attack on humans differs from other wildlife cases [53], since there have never been any cases of hunting and killing of the dragons in the KNP area. According to several authors, several reasons behind the hesitance of killing the Komodo include: First, the conservation status of the Komodo dragon as a protected animal has consequences on criminal sanctions if a person(s) intentionally attacked the animal [54]. Second, there was a very strong cultural bond between the Komodo villagers and the Komodo dragon. Third, Komodo is an animal that will avoid humans, so that conflicts between the two is not expected to be as high as other humanwildlife conflicts [55]. Similar reasons were also forwarded by Verheijen [38]; Brandt [56]; and Endo [42]. 
Table 3. Number of Komodo attacks on local villagers

\begin{tabular}{cllc}
\hline Island & \multicolumn{1}{c}{ Location } & \multicolumn{1}{c}{ Time (year) } & Number of cases \\
\hline \multirow{4}{*}{ Komodo } & Komodo Village & $1996(2), 2000,2001,2003,2007,2017$ & 7 \\
& Loh Liang & 1974,1990 & 2 \\
& Loh Sebita & 2012 & 1 \\
& Loh Srikaya & 2009 & 1 \\
& Loh Wenci & 2014 & 1 \\
\hline \multirow{2}{*}{ Rinca } & Rinca Village & $1981,1982,1987,2012,2013$ & 6 \\
& Kampung Kerora & 1993,1996 & 10 \\
& Loh Buaya & $1997,2005,2009,2010(2), 2012,2013(3), 2017$ & 2 \\
\hline
\end{tabular}

Source: BTNK [50]

Table 4. Frequency of Komodo sightings

\begin{tabular}{lccll}
\hline $\begin{array}{l}\text { Village/ } \\
\text { Frequency }\end{array}$ & Daily & $\begin{array}{l}2-3 \mathrm{x} / \\
\text { Week }\end{array}$ & $\begin{array}{l}1 \mathrm{x} / \\
\text { Week }\end{array}$ & $\begin{array}{l}1 \mathrm{x} / \\
\text { Month }\end{array}$ \\
\hline $\begin{array}{l}\text { Komodo } \\
\begin{array}{l}\text { Village } \\
\text { Rinca }\end{array}\end{array}$ & $57 \%$ & $23 \%$ & $10 \%$ & $10 \%$ \\
Village & $27 \%$ & $23 \%$ & $13 \%$ & $37 \%$ \\
\hline
\end{tabular}

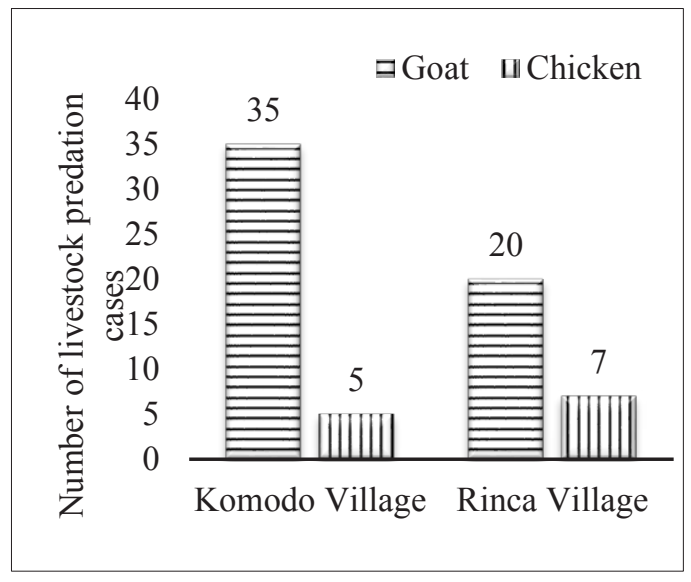

Fig. 3. Komodo's attacks on livestocks in 2018

Despite the low number of attacks on human by Komodo, conflicts with Komodo still occurred since the dragons were often found roaming around within the two villages (Table 4) looking for food (Figure 3), of which most livestock predation involves goats and unconfined poultry. As an opportunistic carnivore, Komodo often found feeding on goats and poultry [57-58], although the natural prey is deer [58]. According to Karanth et al. [59], wildlife attacks on livestock is one of the most common attacks within the human-wildlife conflict realm. As domesticated animals introduced within the Komodo Island [60], both goats and chicken do not have the capability to detect and avoid Komodo as well as deer, wild boar and water buffalo, which have for a long time, been the preys of the Komodos.

Table 4 and Figure 3 indicated that Komodo entered Komodo Village more often than Rinca Village. Figure 3 also indicated that livestock predation occurred more within the Komodo Village. Based on the interviews, as many as $40 \%$ of the villagers kept goats as a sacrifice during Eid al-Adha festivity, $33.3 \%$ as shields from Komodo's attacks of human, while $26.7 \%$ for economic purposes, while villagers in Rinca Island $(100 \%)$ were very dependent on the livestocks to provide for household economy.

The statements by all respondents $(100 \%)$ in both villages justified that the dragons were indeed often found entering the villages (Figure 4) looking for food. The presence of the dragons inside the residential areas was feared by most people (91.5\%). Nevertheless, as many as $48.5 \%$ stated that the Komodo dragon would usually avoid direct contact with humans. As a reaction to the presence of Komodo and cases of Komodo attacks on livestock or humans, most of the population expelled the dragons to avoid possible attacks [52]. Most of the residents of Komodo Village tend to show a reaction by pelting stones $(77 \%)$ to expel the Komodo. In addition, some also showed other reactions such as pulling the tail $(10 \%)$ while $13 \%$ gave no actions. Different than their neighbours in Komodo Village, the people of Rinca Village (50\%), although showed no actions, but would usually report the sightings of Komodo in their village directly to the park officials, while others would pelt stones $(20 \%)$ towards the dragons, hit the animal with wood $(3 \%)$, or heard it with branches $(27 \%)$.

In general, as seen in Figure 4, the people of Komodo and Rinca Villages have different perceptions about their interactions with Komodo. The perception of the community within the Komodo Village falls under the category of "good" with a value of $60.6 \%$, while the perception of community in Rinca Village falls in the category of "medium" $(47.6 \%)$. Furthermore, the Komodo villagers have better response value $(81.5 \%)$ in supporting Komodo conservation compared to Rinca Village (65.3). The high positive perception of the Komodo Villagers towards their interactions with Komodo owned to the belief that the Komodo dragon is their relative $(70 \%)$, while the people of Rinca Village tend to doubt that (53\%). Various research has indicated that human persecution and anti-conservation attitudes towards reptiles could be explained by the presence of folklore and negative values, where the two are interlinked and affected significantly by place of residence, age, and level of education [61]. 


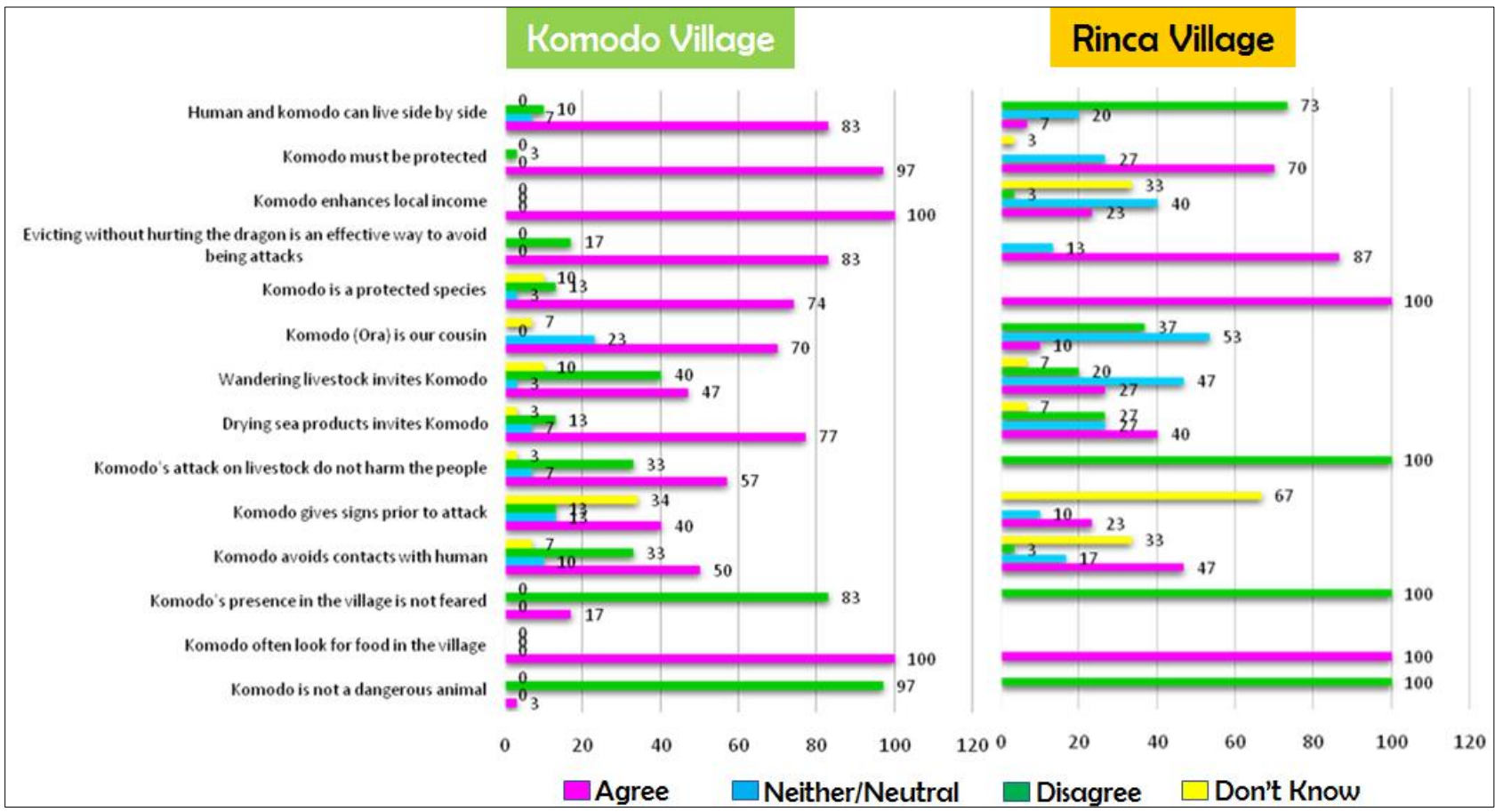

Fig. 4. Perceptions of Komodo and Rinca villagers on Komodo dragon

As seen from Figure 1, Rinca villagers are migrants and do not have any cultural attachment to Komodo. According to some respondents, when they were in Flores, if a conflict occurred with Komodo, they would kill the dragon. The interviews revealed that Komodo was considered by the people of Flores as a pest that should be hunted and killed. A similar statement was also found in Blegur [62]. This started with the change in the status of community land in 1992 and 1996 to 3 protected areas (Wolo Tado Strict Nature Reserve, Riung Strict Nature Reserve, and 17 Islands Marine Tourism Parks). Determination of the status of this area was also followed by the emergence of a ban for the community to burn savanna due to the high frequency of savanna fires so that it affected the deer population which is a prey for the Komodos [62]. The low availability of prey, have increased the livestock predation by the Komodos. This factor also explained the low perception of the community of the Rinca Village on Komodo dragons, given that most people (63\%) originated from Flores (see Figure 1). Therefore, human-Komodo interaction is competitive, in terms of space, as both compete for the same resources within the same space, and these have consequences on the lives of the reptile [1-4] as shown in the perceptions of the Flores people. In addition, Rinca villagers have not received any positive economic impacts from the existence of Komodo.

On the contrary to the community of Rinca Village, the community of Komodo Village has cultural belief that Komodo (Table 5) is their relative. According to the legend, the Komodo people were directly related to the island's endemic dragon. The first Komodo was said to have originated as an abnormal son from the same ancestors as the origin of the Komodo people. According to the Komodo villagers' belief, the Komodo dragon is called Ora [57] and was the twin son of a customary head named Umpu Najo who was born in the form of a dragon and as an adult chose to live in the forest. Such belief of brotherhood with the lizard, has resulted in Komodo people, neither capture nor kill the dragon, but instead bring them food from their fishing and other hunting and gathering activities. Through their cultural beliefs, the Komodo dragon was for a very long time preserved from extinction even before the area was appointed by the government as a protected area. According to the belief, if an Ora is injured, his relatives, who are human, will also become ill [63]. This has led the Komodo Village residents to believe that Ora would not disturb them without reason $[38,56]$. In addition, some of the meat from hunting or fishing were left by the residents for the dragons [64]. This has enabled the residents and Komodo to co-exist (Table 5), despite the high frequency of daily encounter in the village (see Table 4) and the presence of bite cases [56-57, 65] ( see Table 3). This is consistent with Mehta-Erdmann's [66] research, that the inhabitants of Komodo have lived side by side with Komodo dragons for hundreds of years. Table 5 also indicated that there was a difference in the perceptions towards Komodo between the two studied villages. A contradictory result can be seen between the numbers of villagers who have no objections living in close proximity with Komodo, with $83 \%$ of the respondents in Komodo Village showed no objections, while only $7 \%$ of the Rinca villagers agreed to the situation.

It must be taken into account that not all of the misperception about reptiles have resulted directly from folklore. Lack of information on certain spepcies can often lead people to picture the animals as dangerous, lethal or aggressive. It has been previously shown that especially in the case of reptiles, human perception and 
Table 5. Perceptions that support the conservation of Komodo

\begin{tabular}{|c|c|c|c|c|c|c|c|c|c|}
\hline \multirow{2}{*}{ No. } & \multirow{2}{*}{ Statement } & \multicolumn{4}{|c|}{ Komodo Village (\%) } & \multicolumn{4}{|c|}{ Rinca Village (\%) } \\
\hline & & A & $\mathrm{N}$ & $\mathrm{D}$ & DK & A & $\mathrm{N}$ & $\mathrm{D}$ & DK \\
\hline 1 & Komodo (Ora) is our cousin & 70 & 23 & 0 & 7 & 10 & 53 & 37 & 0 \\
\hline 2 & Komodo is a protected species & 73 & 4 & 13 & 10 & 100 & 0 & 0 & 0 \\
\hline 3 & $\begin{array}{l}\text { Evicting without hurting the Komodo is } \\
\text { an effective way to avoid being } \\
\text { attacked }\end{array}$ & 83 & 0 & 17 & 0 & 87 & 13 & 0 & 0 \\
\hline 4 & Komodo increases the local income & 100 & 0 & 0 & 0 & 23 & 40 & 3 & 34 \\
\hline 5 & Komodo should be protected & 97 & 0 & 3 & 0 & 60 & 30 & 7 & 3 \\
\hline 6 & Human and Komodo can co-exist & 83 & 7 & 10 & 0 & 7 & 20 & 73 & 0 \\
\hline
\end{tabular}

Note: $\mathrm{A}=$ Agree; $\mathrm{N}=\mathrm{Neutral} /$ neither; $\mathrm{D}=$ Disagree; $\mathrm{DK}=$ Don't Know

attitude plays a significant role in the effectiveness of local conservation programs. Ceriaco [61] found that in the case of reptiles, the occurrence of folklore and negative values varied significantly with place of residence, age, and level of education [61]. In the same line, Keller [67]; Herzog [68]; Prokop \& Tunnicliffe [9] also added gender, ethnicity, socio-economic level and professional activity, while Stokes [69] and Knight [70] added aesthetics an important determinant of public supports for species protection. The persecution triggered by these factors can be a serious factor that threatens populations of reptiles, since they are the most feared and hated [61].

Forth [32] mentioned that the cultural attachment to the Komodo dragon by the Komodo villagers have caused them to learnt to adapt to the dangers. The Komodo villagers were conscious that the Komodo dragon always provided signs when it would attack humans, such as hissing, approaching and alert positions (40\%), while the majority of the Rinca villagers (67\%) were not aware of these behaviours. In addition, the Komodo dragon attacks were also considered to be very detrimental to the community of Rinca Village (100\%), in contrast to the people of Komodo villagers whom tend not to feel objectionable because livestock were deliberately kept as a shield from the hungry Komodo dragon attacks (57\%). The Komodo Village community also considered that letting livestock roamed would invite the dragons to enter the village area (47\%), while the Rinca villagers tend to doubt that (47\%). Not only livestock, the Komodo villagers believed that drying fish catches would invite the Komodo dragon to enter the village area $(77 \%)$ whereas only $40 \%$ of the people in the Rinca villagers had similar thoughts. As mentioned earlier, $43 \%$ of the respondents in Rinca Island worked as fisherman and many women were also involved in selling dry fishes. Since most of the villagers worked in the field of fisheries, the presence of Komodo feared them.

Basically the community realises that dragons are protected animals $(86.5 \%)$. The people believed that expelling the Komodo dragon without hurting it (by throwing stones and herding) is an effective way (85\%).
Although dangerous, the Komodo dragon is considered to have a positive impact in increasing the income of the community within Komodo Village (100\%) through tourism sector, while only $23 \%$ of the Rinca people felt the positive impact of the Komodo dragon's presence. One obstacle is the poor condition of the pier in Rinca Village, which hinder tourists to come to the island. Even so, similar to the Komodo villagers, the Rinca community also agreed that Komodo is a living creature that must be protected $(78.2 \%)$.

\section{Conclusion}

The residents of Komodo Village were dominated by natives (90\%) with very small population of immigrants, while those of Rinca Village, were dominated by migrants from Flores-Bajo. The majority of Rinca villagers are currently engaging in fisheries as fisherman and dry fish traders, in contrast to Komodo villagers who are mostly engaged in the tourism sector. The perceptions of the Komodo Village community towards their interactions with Komodo were categorised as good (60.6), while the perceptions of the Rinca Village Community were in the moderate category (47.6). As migrants, the Rinca villagers did not have any cultural attachment to the Komodo dragon in addition to not having received any positive impacts from the existence of Komodo.

Despite the results of this research that indicated Komodo was considered the most feared/dangerous among other known reptiles in the KNP, the beliefs of the Komodo villagers that the dragon is their cousins have affected their attitude towards the dragon. Such perceptions have resulted in the approximately $83 \%$ of Komodo villagers believed they could co-exist with the dragons, and showed higher supports for its conservation $(81.5 \%)$ than Rinca villagers $(65.3 \%)$. Komodo villagers tend to avoid direct interactions with the dragon by studying the behaviour of the dragon prior to attacking and make no report to the national park authority. On the contrary, the Rinca villagers, although many would not do anything, but reported the sightings of the Komodo to 
the National Park (NP) authority. This study confirms the importance of integrating local cultural values in building supports for conservation.

This work was supported by the Yayasan Komodo Survival Programme and the University of Florence especially to Dr. Claudio Ciofi for funding this research.

\section{References}

1. D. J. Decker, T. L. Brown, Wildl. Soc. Bull. 10, 150-155 (1982) www.jstor.org/stable/3781735

2. P. Omondi, Wildlife human conflict in Kenya: integrating wildlife conservation with human needs in the Masai Mara Region (Doctoral dissertation, McGill University, Dept. of Geography, Montreal, QC, CA 1994)

3. A. Treves, R. B. Wallace, L. Naughton-Treves, A. Morales, Hum Dimens Wildl. 11, 383-396 (2006) DOI: 10.1080/10871200600984265

4. S. A. Jonker, R. M. Muth, J. F. Organ, R. R. Zwick, W. F. Siemer, Wildl. Soc. Bull. 34, 1009-1021 (2006) DOI: $10.2193 / 0091-$ 7648(2006)34[1009:EWBDAA]2.0.CO;2

5. K. J. Lindsey, C. E. Adams, Hum Dimens Wildl. 11, 267283 (2006) DOI: 10.1080/10871200600803135

6. R. T. Nugraha, J. Sugardjito, Mammal Study, 34, 141-154 (2009) DOI: $\underline{10.3106 / 041.034 .0303}$

7. C. Browne-Nuñez, J. G. Taylor, Americans' Attitudes Toward Wolves and Wolf Reintroduction: An Annoated Bibliography (U.S. Fish and Wildlife Service, New York, 2002).

8. M, Hindrikson, J. Remm, M. Pilot, R. Godinho. Biol Rev, 93, 1601-129 (2017).

9. P. Prokop, S. D. Tunnicliffe, Eurasia j. math. sci. technol. educ. 4, 2 (2008) DOI: 10.12973/ejmste/75309

10. D. S. Fita, E. C. M. Neto, A. Schiavetti, J. Ethnobiol. Ethnomed. 6, 13 (2010) https://doi.org/10.1186/1746$\underline{4269-6-13}$

11. T. Longkumer, L. J. Armstrong, P. Finny, Journal of venom research, 8, 14 (2017)

12. Y. Ke, B. Su, X. Song, D. Lu, L. Chen, H. Li, C. Qil, S. Marzuki, R. Deka, P. Underhill, C. Xiao, M. Shriver, J. Lell, D. Wallace, R. S. Wells, M. Seielstad, P. Oefner, D. Zhu, J. Jin, W. Huang, R. Chakraborty, Z. Chen, L. Jin, Science, 292, 1151-1153 (2001)

13. A. Öhman, A. Flykt, F. Esteves, J. Exp. Psychol. Gen. 130, 466 (2001) DOI: $\underline{10.1037 / 0096-3445.130 .3 .466}$

14. D. G. E. Caldicott, D. Croser, C. Manolis, G. Webb, A. Britton, Wilderness Environ Med, 16, 143-159 (2005)

15. S. D. Ducey, J. S. Cooper, M. C. Wadman, Wilderness Environ Med. 27, 291-293 (2016) https://doi.org/10.1016/j.wem.2016.02.009

16. S. Ramli, Sistem manajemen keselamatan dan kesehatan kerja OHSAS 18001 (PT. Dian Rakyat, Jakarta, 2009)

17. F. Lamarque, J. Anderson, R. Fergusson, M. Lagrange, Y. Osei-Owusu, L. Bakker, Human-wildlife conflict in Africa: causes, consequences and management strategies (FAO, 2009).

18. K. M. Rahman, I. I. Rakhimov, M. M. H. Khan, Annu. res. rev. biol. $1-10$ (2017) DOI: $10.9734 / \mathrm{ARRB} / 2017 / 33970$
19. F. H. Pough, R. M. Andrews, J. E. Cadle, M. L. Crump, A. H. Savitzky, K. D. Wells, Herpetology Prentice Hall (Upper Saddle River, NJ, 1998)

20. D. P. Pandey, G. S. Padney, K. Devkota, M. Goode, J. Ethnobiol. Ethnomed, 12, 1-24 (2016)

21. S. R. Kellert, The value of life: Biological diversity and human society (Island Press, Washington DC, 1996)

22. J. M. Nolan, K. E. Jones, K. W. McDougal, M. J. McFarlin, M. K. Ward, J. Ethnobiol. 26, 126-138 (2006) DOI: $10.2993 / 0278-$ 0771(2006)26[126:TLTLAT]2.0.CO;2

23. L. E. T. Mendonça, W. L. S. Vieira, R. R. N. Alves, Amphib Reptile Conse. 8, 24-32 (2014)

24. S. R. Kellert, Proceedings of the Forty Fifth North American Wildife Conference 45, 111-124. (1980)

25. S. Batt, Biosci. Horiz. 2, 180-190 (2009) https://doi.org/10.1093/biohorizons/hzp021

26. R. R. N. Alves, K. S. Vieira, G. G. Santana, W. L. S. Vieira, W. O. Almeida, W. M. S. Souto, ..., J. C. B. Pezzuti, Environ. Monit. Assess. 184, 6877-6901 (2012) Doi: 10.1007/s10661-011-2465-0

27. M. J. Walpole, N. Leader-Williams, Biodivers Conserv. 11, $\quad 543-547$ https://doi.org/10.1023/A:1014864708777

28. R. A. Pyron, F. T. Burbrink, J. J. Wiens, BMC Evol. Biol. 13, 93 (2013) https://doi.org/10.1186/1471-2148-13-93

29. BPS, Kecamatan Komodo dalam Angka (BPS Manggarai Barat, Manggarai Barat, 2017)

30. BTNK, Statistik Balai TN Komodo tahun 2016 (Balai Taman Nasional Komodo, Labuan Bajo, 2016)

31. J. B. Murphy, T. Walsh, Herpetol. Rev. 37, 269-275 (2006)

32. G. Forth, J. Ethnobiol. 30, 289-307 (2010) https://doi.org/10.2993/0278-0771-30.2.289

33. S. R. Kellert, J. N. Mehta, S. A. Ebbin, L. L. Lichtenfeld, Soc. Natur. Resour. 13, 705-715 (2000)

34. M. Muhumuza, K. Balkwill, Int. J. Biodivers. Conserv (2013) https://doi.org/10.1155/2013/798101

35. I. Dunggio, H. Gunawan, JAKK, 6, 29205 (2009) https://doi.org/10.20886/jakk.2009.6.1.\%25p

36. F. Berkes, Proceedings of the National academy of sciences, 104, 15188-15193 (2007) https://doi.org/10.1073/pnas.0702098104

37. S. Pannell, Transcending the Culture-Nature Divide in Cultural Heritage (ANU Press, Canberra, 2013) DOI: 10.22459/TA36.12.2013.04

38. J. A. J. Verheijen, Pulau Komodo: tanah, rakyat, dan bahasanya (Balai Pustaka, Jakarta, 1987)

39. R. Needham, Bijdragen tot de Taal-, Land-en Volkenkunde, $\quad \mathbf{1 4 2}, \quad 52-68 \quad$ (1986) DOI: $\underline{10.1163 / 22134379-90003368}$

40. G. Forth, Bijdragen tot de Taal-, Land-en Volkenkunde, 44-63 (1988) DOI: $10.1163 / 22134379-90003306$

41. J. Singleton, R. Sulaiman, T. S. Staff, http://www. komodonationalpark. org [accessed on 25 August 2005] (2002)

42. H. Endo, J. Zoo. Wildl. Med. 18, 29-32 (2013). https://doi.org/10.5686/ijzwm.18.29

43. R. Purwatiningsih, Persepsi masyarakat terhadap peranan puskesmas Jatinom dalam pelayanan kesehatan maysrakat di Kelurahan Cengkareng Barat, Jakarta Barat 
(Undergraduate thesis) (Institut Pertanian Bogor, Bogor, 2008)

44. W. Auffenberg, The behavioral ecology of komodo monitor (University Presses of Florida, Gainesville, 1981)

45. J. B. Pittenger, Percept. Psychophys. 48, 124-130 (1990) https://doi.org/10.3758/BF03207078

46. G. C. Davey, Br. J. Psychol. 85, 541-554 (1994) DOI: 10.1111/j.2044-8295.1994.tb02540.x

47. J. Ware, K. Jain, I. Burgess, G. C. Davey, Behav. Res. Ther. 32, 57-63 (1994) https://doi.org/10.1016/00057967(94)90084-1

48. J. Polák, S. Rádlová, M. Janovcová, J. Flegr, E. Landová, D. Frynta, Br. J. Psychol. (2019) DOI:10.1111/bjop.12409

49. P. Ekman, D. Cordaro, Emot. Rev. 3, 364-370 (2011). https://doi.org/10.1177/1754073911410740

50. Balai Taman Nasional Komodo, Statistik Balai TN Komodo tahun 2017 (Balai Taman Nasional Komodo, Labuan Bajo, 2017)

51. R. Rismayani, Buletin Varanus I, 1, 41 (2013)

52. Ardiantiono, Analisis spasial konflik manusia-komodo di Desa Komodo Taman Nasional Komodo (Skripsi) (Universitas Indonesia, Jakarta, 2014)

53. D. G. Caldicott, D. Croser, C. Manolis, G. Webb, A. Britton, Wilderness Environ. Med. 16, 143-159 (2005) DOI: https://doi.org/10.1580/10806032(2005)16[143:CAIAAA]2.0.CO;2

54. M. Indrawan, R. B. Primack, J. Supriatna, Biologi Konservasi: Edisi Revisi (Yayasan Pustaka Obor Indonesia, Jakarta, 2012)

55. A. Seno, Efektivitas jalur-jalur untuk melihat komodo (Varanus komodoensis) di Loh Liang, Pulau Komodo, Taman Nasional Komodo (Doctoral dissertation) (Universitas Gajah Mada, Yogyakarta, 2008)

56. K. Brandt, Mengapa kebudayaan masyarakat kampung Komodo terancam. (Australian National University, Canberra, 2003)
57. W. Auffenberg, The behavioral ecology of komodo monitor (University Press of Florida, Gainesville, 1981)

58. T. Jessop, M. J. Imansyah, D. Purwandana, H. Rudiharto, Ekologi Populasi, reproduksi, dan spasial biawak komodo (Varanus komodo-ensis) di Taman Nasional Komodo, Indonesia. Laporan Akhir. (Taman Nasional komodo, Labuan Bajo, 2007).

59. K. K. Karanth, A. M. Gopalaswamy, R. DeFries, N. Ballal, PloS one, 7, 12 (2012). https://doi.org/10.1371/journal.pone.0050433

60. N. B. Wawandono, R. Djohani, Djuwantoko, L. Habut, A. Marhadi, A. Mehta, Istanto, Rencana pengelolaan 25 tahun Taman Nasional Komodo (Buku 1: rencana pengelolaan) (Balai Taman Nasional Komodo, Labuan Bajo, 2000)

61. L. M. Ceríaco, J. Ethnobiol. Ethnomed. 8, 8 (2012). https://doi.org/10.1186/1746-4269-8-8

62. W. A. Blegur, Vegetasi habitat komodo dalam Bentang Alam Riung, Pulau Ontole dan persepsi masyarakat terhadap komodo Nusa Tenggara Timur (Master Thesis) (Universitas Gadjah Mada, Yogyakarta, 2016)

63. M. Hitchcock, Tourism in south-east Asia (Routledge, London, 1993)

64. C. Ellis, The land of the Komodo Dragon (Times Editions, Singapore, 1998)

65. C. Ciofi, M. E. de Boer, J. Herpetol. 14, 99-107 (2004)

66. A. Mehta-Erdmann, A natural history guide to Komodo National Park. (The Nature conservancy, Indonesia Coastal and Marine Program, Labuan Bajo, 2004)

67. S. R. Kellert, Advances in animal welfare science 1984 (The Humane Society of the United State, Washington DC, 1985)

68. H. A. Herzog, Anthrozoös, 20, 7-21 (2007) https://doi.org/10.2752/089279307780216687

69. D. L. Stokes, Hum. Ecol. 35, 361-369 (2006) DOI: $\underline{10.1007 / \mathrm{s} 10745-006-9056-7}$

70. A. J. Knight, J. Environ. Psychol. 28, 94-103 (2008) DOI: $\underline{10.1016 / \text { j.jenvp.2007.10.001 }}$ 